\title{
Clozapine Efficacy, Type of Titration and Therapeutic Drug Monitoring Using Chemical Methods for Serum Level Assessment
}

\author{
PAULA PETRIC ${ }^{1}$, LORENA DIMA ${ }^{2 *}$, PETRU IFTENI ${ }^{1,2}$, ANDREEA TEO DORESCU1,2*, CLAUDIA GAVRIS ${ }^{2,3 *}$, ALINA MIHAELA PASCU ${ }^{2}$, \\ VLADIMIR POROCH ${ }^{4,5}$, VICTORIA BURTEA ${ }^{2}$ \\ ${ }^{1}$ Clinical Hospital of Psychiatry and Neurology, 7-9 Prundului Str., 500123 Brasov, Romania \\ ${ }^{2}$ Transilvania University of Brasov, Faculty of Medicine, 29 Eroilor Blvd., 500036 Brasov, Romania \\ ${ }^{3}$ Clinical Emergency County Hospital, 25 Calea Bucuresti, 500326 Brasov, Romania \\ ${ }^{4}$ Grigore T. Popa University of Medicine and Pharmacy, Faculty of Medicine, 16 Universitatii Str., 700115 lasi, Romania \\ ${ }^{5}$ Regional Institute of Oncology, 2-4 G-ral Berthelot Str., 700483 Iasi, Romania
}

\begin{abstract}
Approximately $30 \%$ of patients are included in treatment-resistant schizophrenia and clozapine remains the only antipsychotic with proved superior efficacy in these cases. Currently, although clozapine is considered as the most effective pharmacological intervention for treatment-resistant schizophrenia in all national guidelines, its use is suboptimal due to doctors' concerns about tolerability and inappropriate adherence of patients to haematological monitoring required for early detection of severe neutropenia. Although treatment guidelines recommend the use of clozapine starting with a dose of 12.5-25 mg/day and gradual increase over a 2-week period until the therapeutic dose is reached, this recommendation was not derived from rigorous controlled studies. Slow or standard titration of clozapine increases the need for additional psychotropics and risks associated with antipsychotic polypharmacy, and can unnecessarily prolong the patient's suffering and the length of hospitalization. A relationship between a faster titration and a higher incidence of clozapine-induced dangerous adverse effects has not been clearly demonstrated by clinical trials. Therapeutic drug monitoring is of great importance for drugs with a high inter-individual variability in serum concentration, a narrow therapeutic range or serious toxic side effects.
\end{abstract}

Keywords: clozapine, norclozapine, titration, drug monitoring, serum level

Approximately $30 \%$ of patients are included in treatmentresistant schizophrenia (TRS), a phenomenon defined as inappropriate response to two or more antipsychotics ( one of which should be atypical), when given a suitable dose for at least six to eight weeks [1]. According to recently published studies, resistance to treatment has been encountered in some cases since the first episodes. Clozapine has been shown to be the antipsychotic of choice for these patients, a true gold standard. Despite evidence accumulated over 30 years, some physicians are reluctant to prescribe clozapine, probably because of the side effects reported, including agranulocytosis and myocarditis, although rare, but potentially life-threatening. The results reported at that time did not take into account the existence of factors such as benign ethnic neutropenia, inter-racial or inter-individual variability of clozapine metabolism, or drug interactions that might increase the plasma levels of $\mathrm{N}$-desmethylclozapine (norclozapine), the active metabolite of clozapine [2].

Clozapine is metabolized predominantly by $\mathrm{N}$ demethylation, $\mathrm{N}$-oxidation, and aromatic hydroxylation. The main cytochrome P-450 hepatic isoenzymes involved in its metabolism are CYP1A2 and CYP3A4. In vitro data also show that CYP2D6, CYP2C19, and CYP2C9 play a role. Norclozapine (N-desmethylclozapine) and clozapine-Noxide are the two primary active metabolites obtained by hepatic metabolism, with the former being more active. The involvement of the cytochrome P450 enzymatic system, as one would expect, means that clozapine has an extensive list of pharmacokinetic interactions. Some of these interactions are not always apparent and may not be routinely flagged by drug-interaction programs. These include induction of metabolism by the polycyclic aromatic hydrocarbons in cigarette or cannabis smoke, inhibition of metabolism by caffeine consumption, and other variables such as age, race, and gender [3-7].

There was a need for a comprehensive clinical trial such as the one performed by J ohn Kane, following which the use of clozapine was approved for refractory schizophrenia by the Food and Drug Administration (FDA) in the US, in 1989 [8].

Currently, although clozapine administration is considered the most effective pharmacological intervention for TRS in all national guidelines, its use is suboptimal because of doctors' concerns abouttolerability and inappropriate adherence of patients to haematological monitoring required for early detection of severe neutropenia. Side effects cause discontinuation of clozapine treatment in $17 \%$ of cases, often erroneous, for effects that would ameliorate over time (sinus tachycardia, sedation, hypersalivation, etc.), despite the favorable risk / benefit ratio [9]. Recent papers present successful rechallenge of clozapine [10, 11].

Treatment guidelines recommend the use of clozapine starting with a dose of $12.5-25 \mathrm{mg} /$ day and gradual increase over a 2-week period until the therapeutic dose is reached. The one size fits all conservative approach ignores the substantial differences in bioavailability observed after administration of clozapine, a heterogeneity partly explained by the large number of genes that contribute to cytochrome P-450 metabolism. In addition, standard titration slows the control of psychotic symptoms, increases the need for additional psychotropics, antipsychotic polypharmacy, potentiating pharmacological interventions, and can unnecessarily prolong the patient's suffering and length of hospitalization.

Underuse of clozapine and overuse of antipsychotic polypharmacy have been both associated with poor quality 
of care [12-14]. One of the reasons of clozapine underuse is the inconsistence of the reports concerning clozapine oral dose and serum level.

For clozapine, the therapeutic range defined by the AGNP (Arbeitsgemeinschaftfür Neuropsychopharmakologie und Pharmakopsychiatrie) Consensus Guidelines is 350 to 600 $\mathrm{ng} / \mathrm{mL}$. The most frequently prescribed and most effective dose of 350-550 mg clozapine per day is associated with mean serum concentrations of $350 \mathrm{ng} / \mathrm{mL}$. According to published data, concentrations in the range of $250 \mathrm{ng} / \mathrm{mL}$ could be adequately once symptoms are controlled. Concentration above $600-1000 \mathrm{ng} / \mathrm{mL}$ are associated with serious side effects. For norclozapine, the therapeutic range as defined by AGNP is $100-600 \mathrm{ng} / \mathrm{mL}$. 323 of the 330 serum samples contained clozapine and 324 of the 330 contained norclozapine. For clozapine, only $22.3 \%$ of the serum concentrations were within the therapeutic range. $21.8 \%$ of the serum concentrations were between 250 $350 \mathrm{ng} / \mathrm{mL}$, which can still be adequate when symptoms are controlled. Overall, $67.9 \%$ of the serum levels were < $350 \mathrm{ng} / \mathrm{mL}$. In comparison, Couchman et al. found $42.5 \%$ of the serum samples $<350 \mathrm{ng} / \mathrm{mL}$. Since the administered dose was lacking, it is difficult to address these subtherapeutic concentrations to non-compliance, to underdosing, or to start-up of the therapy. $68.4 \%$ of the norclozapine concentrations were found within the proposed therapeutic range. Despite its doubtful activity, monitoring of this metabolite has some advantages, because norclozapine has a longer half-life and less dayto-day variability [15-18].

\section{Experimental part}

\section{Monitoring clozapine and norclozapine}

Pharmacokinetics (PK) software based on Bayesian analysis was used to calculate the PK parameters of clozapine and CYP1A2, which is an isozyme of the cytochrome P-450 (CYP); clozapine activity and clearance, were estimated. Caffeine clearance was used for an estimation of CYP1A2 activity.

Results have shown that there was a significant relationship between the clozapine clearance and clozapine dose (R: 0.71; P < 0.05) and that the CYP1A2 activity was important for clozapine dosing [19].

Another assessment method was flow-injection tandem mass spectrometry (FIA-MS/MS) with automated extraction (sing novel AC Extraction Plates and a Tecan Freedom EVO 100 liquid handling platform), which helped to rapid reporting of results and minimized analysis time. The results showed excellent intraplate and interplate accuracy ( $95 \%-104 \%$ nominal concentrations).

The process efficiency was $56-70 \%$ for clozapine, and $66-77 \%$ for norclozapine. The mean relative process efficiency was $98 \%$ for clozapine and $99 \%$ for norclozapine [20].

Clozapine was determined also in hair and nails. A study that showed the role of keratinous biological materials claimed that these materials, compared to other body fluids, offered a longer retrospective window of detection. The study was done on hair and nails from a dead body of a patient with prolonged use of clozapine with ultraperformance liquid chromatography tandem mass spectrometer (UPLC-MS/MS). Clozapine was detected in hair (322.9 pg/mg) and nails (138.3 pg/mg) [21].

\section{Titration}

In experienced psychiatric emergency units the fast or rapid titration was successfully used in schizophrenia and in treatment-refractory mania [22-24].
The meaning of rapid titration of clozapine is variable. In 2017, Clozapine Management Clinical Guideline of South Australia Government, the rapid clozapine titration protocols indicated that clozapine could be titrated up to $125 \mathrm{mg}$ in the first 7 days, and up to $300 \mathrm{mg}$ at the end of the first 2 weeks. However, the drug was introduced by slow titration, usually starting with $12.5 \mathrm{mg}$ on day $1,25 \mathrm{mg}$ on day 2,50 $\mathrm{mg}$ on day 3 , and then up to the required dose. So, comparing standard titration ( $200 \mathrm{mg}$ at the end of the first 14 days) with rapid titration ( $300 \mathrm{mg}$ at the end of the first 14 days) it is difficult to observe an important difference [12]. Clozapine initiation in crises team proposed in United Kingdom showed an average titration time of 34.5 days $(S D=20.3)$, which can generate conditions for dropout and high costs $[25,26]$.

One of the advantages of a fast titration regimen might be the benzodiazepines avoidance, as these combinations have sometimes been associated with an increased risk of sudden death. In the studies performed in our clinic, we avoided concomitant mood stabilizers and benzodiazepines during titration, which led to a more clean treatment regimen and less possible side effects [27, 28].

Usually, in a rapid titration, the therapeutic doses are reached in 4-5 days. Treatment is starting with $12.5 \mathrm{mg}$ and increased at $6-12 \mathrm{~h}$. A possible disadvantage of a fastdosing regimen is that patients may be at higher doses than necessary, but the reports on this topic are still controversial.

Clozapine is available exclusively as oral formulations (tablet and oral solutions in some European countries, but not in Romania), which can make it difficult to administer to violent or aggressive patients. How ever, when administered, it resulted in a significant reduction of aggressiveness in schizophrenia. Efficacy was reported also for other conditions such as maniac refractory episode, challenging behavior in dementia or in individuals with intellectual disability, as off-label treatment [29]. In such cases, clozapine was often rapidly titrated. Rapid clozapine titration is useful in patients with schizophrenia and physical violence, self-mutilation or risk of suicide. Last but not least, the use of clozapine was correlated with decreasing the need, duration and number of mechanical restraint [30].

Reduction of relapses and admissions are considered the most important aspects of antipsychotic efficacy. Clozapine was found to be the second best antipsychotic in reduction of rehospitalization in schizophrenia after olanzapine LAl (long-acting injectable) [31].

Recent studies have shown that in schizophrenia, clozapine has caused declining mortality from any cause [32-34]. A study evaluating the correlation between antipsychotics and sudden death in schizophrenia found no link with clozapine [35]. Regulations of clozapine vary widely with regard to rules of prescribing, indications, dosing and monitoring [36]. In 2014, Dan Cohen pointed that Fear remained the major side-effects of clozapine. False beliefs of psychiatrists that patients treated with clozapine were less satisfied with their treatment when compared to those treated with other atypical antipsychotics, or lack of experience and knowledge of clozapine pharmacological properties are reasons for underutilization [37].

\section{Conclusions}

Differences between standard and rapid clozapine titration might have important medical and pharmacoeconomical implications. Further studies comparing fast vs. standard titration are needed, as well as a better training 
of psychiatristin clozapine indications, initiation procedures and monitoring.

Therapeutic drug monitoring is of great importance for drugs with a high inter-individual variability in serum concentration, a narrow therapeutic range or serious toxic side effects.

\section{References}

1.KANE, J.M., AGID, O., BALDWIN, M.L., HOWES, O., LINDENMAYER, J.P., MARDER, S., OLFSON, M., POTKIN, S.G., CORRELL, C.U., J . Clin. Psychiatry, 80, no. 2, 2019, pii: 18com12123. doi: 10.4088/ JCP.18com12123.

2.MANU, P., SARVAIYA, N., ROGOZEA, L.M., KANE, J.M., CORRELL, C.U., J. Clin. Psychiatry, 77, no. 7, 2016, p. e909.

3.COUCHMAN, L., MORGAN, P.E., SPENCER, E.P., FLANAGAN, R.J ., Ther. Drug Monit., 32, no. 4, 2010, p. 438.

4.SERBAN, I.L., ALEXINSCHI, O., PADURARIU, M., MADALINA, D., CIOBICA, A., TIMOFTE, D., ANTON, E., ANTON, C., Archives of Biological Sciences, 67, no. 1, 2015, p. 283. DOI: 10.2298/ABS141113039S 5.ZULLINO, D.F., DELESSERT, D., EAP, C.B., PREISIG, M., BAUMANN, P., Int. Clin. Psychopharmacol., 17, no. 3, 2002, p. 141.

6.DE LEON, J., Psychiatr. Serv., 55, no. 5, 2004, p. 491.

7.PAULET, M., CIOBICA, A., COJOCARU, S., POPESCU, R., TIMOFTE, D., Archives of Biological Sciences, 67, no. 4, 2015, p. 1425. DOI: 10.2298/ABS140505122P

8.KANE, J.M., HONIGFELD, G., SINGER, J., MELTZER, H., Psychopharmacol. Bull., 24, no. 1, p. 62.

9.NIELSEN, J., CORRELL, C.U., MANU, P., KANE, J.M., J. Clin. Psychiatry, 74, no. 6, p. 603.

10.MANU, P., LAPITSKAYA, Y., SHAIKH, A., NIELSEN, J., Am. J. Ther., 25, no. 5, 2018, p. e218.

11.MANU, P., SARPAL, D., MUIR, O., KANE, J.M., CORRELL, C.U., Schizophr. Res., 134, no. 2-3, 2012, p. 180. doi: 10.1016/ j.schres.2011.10.014. Epub 2011 Nov 22. Review.

12.TANG, Y., HORVITZ-LENNON, M., GELLAD, W.F., LAVE, J .R., CHANG, C.H., NORMAND, S.L., DONOHUE, J.M., Psychiatr. Serv., 68, no. 6, 2017, p. 579.

13.TEODORESCU, A., IFTENI, P., PETRIC, P., TOMA, S., BARACAN, A., GAVRIS, C., BALAN, G.G., POROCH, V., PASCU, A.M., Rev. Chim. (Bucharest), 68, no. 12, 2017, p. 2952.

14.FODOR, A.A., PASCU, A.M., POROCH, V., IFTENI, P., BURTEA, V., TOMA, S., BARACAN, A., GAVRIS, C., TEODORESCU, A., Rev. Chim. (Bucharest), 69, no. 3, 2018, p. 650.

15. HIEMKE, C., BAUMANN, P., BERGEMANN, N., CONCA, A., DIETMAIER, O., EGBERTS, K., FRIC, M., GERLACH, M., GREINER, C., GRUNDER, G., HAEN, E., HAVEMANN-REINECKE, U., JAQUENOUD SIROT, E., KIRCHHERR, H., LAUX, G., LUTZ, U.C., MESSER, T., MÜLLER, M.J., PFUHLMANN, B., RAMBECK, B., RIEDERER, P., SCHOPPEK, B., STINGL, J., UHR, M., ULRICH, S., WASCHGLER, R., ZERNIG, G., Pharmacopsychiatry, 44, 2011, p. 195.

16.PATTEET, L., MAUDENS, K.E., SABBE, B., MORRENS, M., NEELS, H., Clin. Chim. Acta, 429, 2014, p. 51.
17.COUCHMAN, L., MORGAN, P.E., SPENCER, E.P., FLANAGAN, R.J., Ther. Drug. Monit., 32, 2010, p. 438.

18.AGEU, L., TALPOS, C., KANALAS, G., CRISAN, S., ZAMFIR, C.L., POROCH, V., ANGHEL, M., Rev. Chim. (Bucharest), 69, no, 3, 2018, p. 621.

19.DOUDE VAN TROOSTWIJK, L.J., KOOPMANS, R.P., VERMEULEN, H.D., GUCHELAAR, H.J ., European J ournal of Pharmaceutical Sciences, 20, no. 4-5, 2003, p. 451.

20.COUCHMAN, L., SUBRAMANIAM, K., FISHER, D.S., BELSEY, S.L., HANDLEY, S.A., FLANAGAN, R.J., Therapeutic Drug Monitoring, 38, no. 1, 2016, p. 42.

21.CHEN, H., XIANG, P., SHEN, M., Journal of Forensic and Legal Medicine, 22, 2013, p. 62.

22.IFTENI, P., CORRELL, C.U., NIELSEN, J., BURTEA, V., KANE, J.M., MANU, P., J. Affect. Disord., 166, 2014, p. 168. doi: 10.1016/ j.jad.2014.04.020. Epub 2014 May 20.

23.IFTENI, P., NIELSEN, J., BURTEA, V., CORRELL, C.U., KANE, J.M., MANU, P., Acta Psychiatr. Scand., 130, no. 1, 2014, p. 25. doi: 10.1111/ acps.12241. Epub 2013 Dec 20.

24.IFTENI, P., TEODORESCU, A., MOGA, M.A., PASCU, A.M., MICLAUS, R.S., Neuropsychiatric disease and treatment, 13, 2017, p. 201. DOI: 10.2147/NDT.S122367.

25.*** https://www.sahealth.sa.gov.au/wps/wcm/connect/public + content/sa+health+internet/clinical+resources/clinical+topics/ medicines+and+drugs/clozapine/treating+ patients+on+clozapine 26.GONZALEZ, C., KODIMELA, K., POYNTON, A., BJ MP, 6, no. 3, 2013, p. a624.

27.RONALDSON, K.J ., FITZGERALD, P.B., TAYLOR, A.J., TOPLISS, D.J ., WOLFE, R., MCNEIL, J.J. Schizophr. Res., 141, no. 2-3, 2012, p. 173. 28.ROHDE, C., HILKER, R., SISKIND, D., NIELSEN, J., J. Psychopharmacol., 32, no. 11, 2018, p. 1197.

29.TEODORESCU, A., DIMA, L., IFTENI, P., ROGOZEA, L.M., Am. J. Ther., 25, no. 3, 2018, p. e320.

30.IFTENI, P., SZALONTAY, A.S., TEODORESCU, A., Am. J. Ther., 24, no. 2, 2017, p. e222.

31.TAIPALE, H., MEHTÄLÄ, J., TANSKANEN, A., TIIHONEN, J ., Schizophr. Bull., 44, no. 6, 2018, p. 1381.

32.TORNIAINEN, M., MITTENDORFER-RUTZ, E., TANSKANEN, A., BJ ORKENSTAM, C., SUVISAARI, J., ALEXANDERSON, K., TIIHONEN, J., Schizophr. Bull., 41, no. 3, 2015, p. 656.

33.KANE, J.M., Am. J. Psychiatry, 174, no. 10, 2017, p. 920.

34.VERMEULEN, J.M., VAN ROOIJEN, G., VAN DE KERKHOF, M.P.J ., SUTTERLAND, A.L., CORRELL, C.U., DE HAAN, L., Schizophr. Bull., 45, no. 2, 2019, p. 315.

35.IFTENI, P., CORRELL, C.U., BURTEA, V., KANE, J.M., MANU, P., Schizophr. Res., 155, no. 1-3, 2014, p. 72.

36.NIELSEN, J., YOUNG, C., IFTENI, P., KISHIMOTO, T., XIANG, Y.T., SCHULTE, P.F., CORRELL, C.U., TAYLOR, D., CNS Drugs, 30, no. 2, 2016, p. 149.

37.NIELSEN, J., DAHM, M., LUBLIN, H., TAYLOR, D., J. Psychopharmacol., 24, no. 7, 2010, p. 965.

Manuscript received: 17.12 .2018 